Katarzyna Derlatka

Uniwersytet Łódzki

(iD

ORCID ID: 0000-002-8120-6478
OBLICZA WOJNY

TOM 2 - ARMIA KONTRA NATURA

ŁóDŹ 2020 • ISBN 978-83-8220-057-7 • s. 359-377

http://dx.doi.org/10.18778/8220-057-7.17

\title{
ROLA AMERYKAŃSKIEJ GWARDII NARODOWEJ, WOJSKA ORAZ SI $Ł$ NATO PRZED, W TRAKCIE I PO USTĄPIENIU HURAGANU KATRINA
}

\begin{abstract}
Streszczenie. Na przełomie sierpnia i września 2005 r. amerykańskie mocarstwo okazało się bezradne wobec potęgi huraganu Katrina, który dokonał zniszczeń na obszarze 234000 km² w 19 stanach. Katrina została nazwana największą katastrofą dla Stanów Zjednoczonych Ameryki Północnej, była lekcją pokory dla władz, udowodniła również, że należy być przygotowanym na każdą ewentualność, przewidywać możliwie dużo scenariuszy rozwoju wydarzeń przy każdym zidentyfikowanym zagrożeniu. Jedną z przyczyn poniesienia dużych strat ludzkich i materialnych był brak opracowanego i wdrożonego krajowego, ramowego planu reagowania kryzysowego, który by zakładał obowiązkową wcześniejszą ewakuację ludności i szybsze zaangażowanie służb oraz, jeśli to konieczne, wojska. W akcji ratowniczej w trakcie i po ustąpieniu huraganu Katrina uczestniczyło 72000 żołnierzy, w tym aż 50000 żołnierzy Gwardii Narodowej. Na pomoc ofiarom kataklizmu wysłano okręty wojenne, samoloty transportowe i helikoptery. Wojsko pomagało w rozdzielaniu żywności i lekarstw, w ewakuacji, w akcjach ratowniczych, transporcie darów i niezbędnych do życia środków. Operacje wojskowe prowadzone w odpowiedzi na huragan Katrina były wieloaspektowe. W fazie reagowania, która była prowadzona również po ustąpieniu huraganu, prowadzono operacje poszukiwawczo-ratownicze prowadzone głównie przez śmigłowce, ewakuację ludności przez naziemne środki transportu oraz operacje pomocy, w tym transport dostaw, usuwanie śmieci, przywrócenie krytycznych sieci transportowych i komunikacyjnych, a także operacje poszukiwania i ratowania. Skala zniszczeń podczas huraganu Katrina spowodowała też konieczność wykorzystania wsparcia NATO.
\end{abstract}

Słowa kluczowe: reagowanie kryzysowe, huragan Katrina, kataklizmy, Stany Zjednoczone, NATO, Gwardia Narodowa, armia amerykańska 


\section{Supermocarstwo w obliczu żywiołu}

Na przełomie sierpnia i września 2005 r. amerykańskie mocarstwo okazało się bezradne wobec potęgi huraganu Katrina, który dokonał zniszczeń na obszarze $234000 \mathrm{~km}^{2}$ w 19 stanach $^{1}$. Brytyjski dziennik „The Telegraph” napisat, że sity natury w sposób niewyobrażalny unicestwiły struktury społeczne i rzuciły amerykańskie mocarstwo na kolana². Dla porównania obszar Polski to $312679 \mathrm{~km}^{2}$. Gdyby taki kataklizm dotknął Polski, kraj byłby w ruinie, a odbudowa trwałaby długie lata.

Huragan przemierzał południowo wschodnie obszary Stanów Zjednoczonych Ameryki Północnej od 23 do 30 sierpnia 2005 r. Kataklizm pochłonął 1836 ofiar, a 705 osób uznano za zaginione. Łącznie ewakuowano $80 \%$ z 1,3 mln obywateli ${ }^{3}$ zamieszkałych na tym obszarze, a straty powstałe $w$ wyniku przejścia huraganu, na podstawie doniesień Agencji Reutera, przekroczyły 200 miliardów dolarów ${ }^{4}$. Według danych Departamentu Obrony Stanów Zjednoczonych w akcji ratowniczej uczestniczyło 72000 żołnierzy, w tym 50000 z Gwardii Narodowej5. Na pomoc ofiarom kataklizmu wysłano okręty wojenne, samoloty transportowe i helikoptery.

Dlaczego amerykański system zarządzania kryzysowego, wyposażony w duże siły i środki, nie poradził sobie z żywiołem, który był znanym, przewidywanym zagrożeniem, występującym regularnie na południowo wschodnim obszarze Stanów Zjednoczonych? Zawsze niewiadomą jest siła, z jaką uderzy żywioł i jego trajektoria. Według raportu Specjalnej Komisji Izby Reprezentantów na temat huraganu Katrina ${ }^{6}$ i dotyczących go ocen, zawiodły niewłaściwe

${ }^{1}$ https://www.tygodnikprzeglad.pl/nowy-orlean-po-potopie/ [dostęp: 20 IX 2019].

2 Ibidem.

${ }^{3}$ https://tvnmeteo.tvn24.pl/informacje-pogoda/swiat27/10-lat-temu-przeszla-katrina-zginelo-1836-osob, 177063,1,0.html [dostęp: 20 IX 2019].

${ }^{4}$ https://wiadomosci.wp.pl/bilans-huraganu-katrina-6037193376342657a [dostęp: 20 IX 2019].

5 J.A. Wombwell, Army Support During the Hurricane Katrina Disaster, „The Long War Series Occasional Paper” 29, Leavenworth 2009, s. 195. https://www.armyupress.army.mil/Portals/7/ combat-studies-institute/csi-books/wombwell.pdf [dostęp: 24 IX 2019].

${ }^{6}$ Hurricane Katrina: A Nation Still Unprepared. Special Report Of The Committee On Homeland Security And Governmental Affairs United States Senate Together With Additional View, $109^{\text {th }}$ Congress $2^{\text {nd }}$ Session, Washington, 2006, https://www.congress.gov/109/crpt/srpt322/CRPT-109srpt322.pdf [dostęp: 20 IX 2019]. 
procedury, brak ramowych zasad działania na wypadek wystąpienia tak rozległego i potężnego zagrożenia oraz pojawiły się problemy z koordynacją działań wojska. Zaprezentowany poniżej skrót wydarzeń odnoszących się do przemieszczania się huraganu Katrina nad terytorium USA, ma na celu ukazanie problemów, z jakimi miały do czynienia władze amerykańskie, i udzielenie odpowiedzi na pytanie, dlaczego żadna siła militarna i cywilna nie byłaby w stanie poradzić sobie ze skutkami takiej katastrofy.

Senat USA we wspomnianym powyżej raporcie opublikowanym po katastrofie zawarł wiele uwag na temat przygotowań, prognozowania, wszystkich działań cywilnych i wojskowych, po to, żeby w przyszłości udoskonalić system i zwiększyć bezpieczeństwo. Ale nawet, gdyby wdrożono te wszystkie zalecenia przed katastrofą, nadal byłoby to nieadekwatne wobec potęgi natury, z jaką miano tu do czynienia. Człowiek nie jest w stanie odeprzeć sił natury, może jednak się na nie przygotować, ale w stopniu wystarczającym tylko według jego przewidywania, a rzeczywistość może być nieprzewidywalna, dobrane zaś siły i środki zbyt małe. Tak było właśnie podczas omawianego huraganu.

Huragan przemierzał obszar Stanów Zjednoczonych w dniach 23-30 sierpnia 2005 r. W dniu 24 sierpnia osiągnął I stopień według pięciostopniowej skali Saffira-Simpsona. Gdy zbliżał się do Florydy, prędkość wiatru osiągnęła $120 \mathrm{~km} / \mathrm{h}$. Na uwagę zasługuje fakt, że mieszkańcy tego stanu nie wiedzieli nic o nadchodzącej katastrofie, ponieważ rząd nie podał tych informacji do mediów. Potem huragan osłabł na lądzie, by znowu przybrać na sile przemieszczając się nad Zatoką Meksykańską. W dniu 26 sierpnia Katrina została zaklasyfikowana jako huragan III kategorii, wiatr wiał z prędkością ponad $200 \mathrm{~km} / \mathrm{h}$. Straż Przybrzeżna rozpoczęła działania przygotowawcze w prognozowanej strefie uderzenia, mobilizując do działania ponad czterystu rezerwistów. Samorządy lokalne wydały rozporządzenia o ewakuacji ludności. Centrum Treningu Lotnictwa (Aviation Training Center) włączyło się do akcji ewakuacyjnej poprzez zlecenie swoim załogom pomocy ratownikom.

Ewakuacją objęto stany Luizjana, Missisipi i Alabama. Nakazano także przymusową ewakuację Nowego Orleanu. Oddziały Gwardii Narodowej w Missisipi rozpoczęły przygotowania do nadejścia huraganu. Prezydent USA George W. Bush wprowadził stan wyjątkowy w Luizjanie, Missisipi i Alabamie?

\footnotetext{
7 Ibidem.
} 
Jednak zanim huragan dotarł do kontynentalnej części Stanów Zjednoczonych, osiągnął $\mathrm{V}$, najwyższą kategorię. Wiatr wiał z prędkością ponad $280 \mathrm{~km} / \mathrm{h}^{8}$. Tak zmienna amplituda kataklizmu zaskoczyła władze i służby ratunkowe, które z dużym opóźnieniem ogłosiły ewakuację ludności.

Katrina została nazwana największą katastrofą w historii Stanów Zjednoczonych. Jedną z przyczyn poniesienia tak dużych strat ludzkich i materialnych był brak opracowanego i wdrożonego krajowego, ramowego planu reagowania kryzysowego. Katrina okazała się lekcją pokory dla władz, dowiodła, że należy być przygotowanym na każdą ewentualność, przewidzieć możliwie dużo scenariuszy rozwoju wydarzeń przy każdym zidentyfikowanym zagrożeniu. Władze amerykańskie były prawdopodobnie zbyt pewne siebie, swojej siły, potęgi militarnej i gospodarczej, dlatego nie doceniły siły natury. Opozycyjna wówczas Partia Demokratyczna oskarżyła prezydenta Busha o to, że pieniądze przeznaczone na wzmocnienie wałów przeciwpowodziowych wokół Nowego Orleanu wydał na wojnę w Iraku, a żołnierze, którzy mogliby pomagać powodzianom, pełnili tam służbę 9 . Mimo takich krytycznych uwag, w rzeczywistości liczba zaangażowanego wojska była jednak adekwatna do rozmiaru kataklizmu i skali zniszczeń. Władze cywilne nie są w stanie zrealizować wielu zadań z dziedziny bezpieczeństwa w takich sytuacjach bez pomocy wojskowej. Natomiast błędy w działaniu w zakresie zarządzania sytuacją kryzysową, lekceważenie ostrzeżeń o zbliżającym się kataklizmie przez Departament Bezpieczeństwa Krajowego i podległą mu Agencję Zarządzania Kryzysowego ukazuje raport Specjalnej Komisji Izby Reprezentantów dotyczący huraganu Katrina ${ }^{10}$. Winą za tragedię obarczono władze stanu Luizjana i miasta Nowy Orlean oraz republikańskie władze federalne.

Podczas huraganu Katrina najbardziej zniszczone zostało miasto Nowy Orlean. Problemem był nie tylko huragan, ale także powódź i rozboje. Po przejściu huraganu służby nie od razu zaczęły pomagać i ewakuować rannych. Wielu poszkodowanych zmarło z powodu zbyt długiego czasu oczekiwania na pomoc. Ewakuacja nie objęła wszystkich mieszkańców, a władzom zarzucano

8 A.C. Anderson, The New Orleans Hurricane Protection System: What Went Wrong and Why, American Society of Civil Engineers, 2007, s. 12-13, https://biotech.law.lsu.edu/katrina/reports/ erpreport.pdf [dostęp: 22 IX 2019].

${ }^{9}$ https://www.tygodnikprzeglad.pl/nowy-orlean-po-potopie/ [dostęp: 20 IX 2019].

${ }^{10}$ Hurricane Katrina: A Nation Still... 
sprowadzenie niewystarczających sił wojska i policji w celu zapewnienia porządku i bezpieczeństwa, co powodowało wzrost przestępczości. Problemem była także niedostateczna ilość wody, jedzenia i lekarstw ${ }^{11}$.

\section{System zarządzania kryzysowego w Stanach Zjednoczonych}

Zgodnie z Konstytucją Stanów Zjednoczonych Ameryki i Ustawa o Bezpieczeństwie Państwa z 1947 r. za bezpieczeństwo państwa odpowiedzialny jest prezydent. Jego organem doradczym w zakresie bezpieczeństwa państwa jest Rada Bezpieczeństwa Narodowego. Prezydent tworzy politykę państwa ds. zwalczania i likwidowania skutków wszelkiego rodzaju zagrożeń występujących w skali kraju. Za realizację tej polityki na poziomie federalnym odpowiada Federalna Agencja Zarządzania Kryzysowego (Federal Emergency Management Agency - FEMA), wchodząca w skład Departamentu Bezpieczeństwa Wewnętrznego ${ }^{12}$.

Reagowanie na sytuacje kryzysowe w Stanach Zjednoczonych jest przede wszystkim zadaniem władz lokalnych i stanowych. Rząd federalny odgrywa rolę wspierającą, uznając, że władze lokalne i stanowe są w stanie najlepiej zrozumieć potrzeby obywateli i szybko reagować. Jeśli władze stanowe i lokalne nie są w stanie poradzić sobie z sytuacją, zwracają się o pomoc do instytucji cywilnych, a następnie wojskowych w rządzie federalnym ${ }^{13}$. Na poziomie stanowym zwalczaniem i likwidowaniem skutków zagrożeń kieruje gubernator. W razie konieczności może on wprowadzić stan wyjątkowy (stan klęski żywiołowej), uruchamia wówczas Stanowy Plan Ratowniczy oraz wzywa Gwardię Narodową ${ }^{14}$.

${ }^{11}$ G. KILJAN, Krajowy system zarządzania kryzysowego w środowisku sieciocentrycznym, „Studia i Materiały Polskiego Stowarzyszenia Zarządzania Wiedzą” 2010, nr 33, s. 62.

12 https://www.fema.gov/about-agency [dostęp: 21 IX 2019].

13 J. FALECKI, Analiza systemów zarządzania kryzysowego wybranych państw w aspekcie bezpieczeństwa powszechnego, „Zeszyty Naukowe Wyższej Szkoły Humanitas. Zarządzanie” 2017, t. 18, nr 2, s. $113-115$.

${ }^{14}$ Gwardia Narodowa jest organizacją wojskową o charakterze terytorialnym, jej placówki rozlokowane są na terenie całego kraju. Obecnie na obszarze Stanów Zjednoczonych funkcjonuje blisko trzy tysiące jednostek Gwardii Narodowej, które zapewniają wsparcie o różnym charakterze w obszarze bezpieczeństwa. Dzięki temu obojętne jest, czy wezwanie mobilizacyjne pochodzi od gubernatora stanu czy prezydenta USA. Gwardziści są zawsze gotowi i zawsze na miejscu (Guard Soldiers are always ready and always there), zakres zaś ich zadań i obszar działania obejmuje właściwie wszystko to, 
Gdy sytuacje kryzysowe przekraczają możliwości reagowania stanu, określane są mianem stanu zagrożenia lub stanu poważnej klęski żywiołowej. Gubernator zwraca się do prezydenta o ich ogłoszenie. Natomiast na poziomie lokalnym zarządzanie kryzysowe jest w gestii burmistrza ${ }^{15}$.

Planowanie i reagowanie na klęski żywiołowe i katastrofy zostało określone w Krajowym Planie Reagowania (National Response Plan - NRP), wydanym w 2004 r. i zmienionym w następstwie huraganu Katrina ${ }^{16}$. Z dokumentu jasno wynika, że zgodnie z Konstytucją Stanów Zjednoczonych, planowanie i przygotowywanie się do klęsk żywiołowych lub innych sytuacji kryzysowych oraz reagowanie na nie są przede wszystkim obowiązkami poszczególnych stanów. NRP opiera się na Krajowym Systemie Zarządzania Incydentami (National Incident Management System - NIMS), który określa spójne ramy zarządzania incydentami w całym kraju, niezależnie od szczebla rządowego. Centralnym składnikiem NIMS jest System Zarządzania Incydentami ${ }^{17}$, który zapewnia środki do koordynowania reakcji poprzez pięć głównych obszarów funkcjonalnych (dowodzenie, planowanie, operacje, logistyka oraz finanse/administracja). Podsumowując, NRP i NIMS tworzą ujednoliconą strukturę zarządzania w zakresie wszystkich zagrożeń - zarówno spowodowanych przez człowieka, jak i naturalnych, w jurysdykcjach lokalnych, stanowych i federalnych ${ }^{18}$.

FEMA odpowiada za monitoring zagrożeń, planowanie i koordynację działań sił biorących udział w zapobieganiu klęskom żywiołowym i katastrofom oraz usuwaniu ich skutków. Na poziomie federalnym agencja jest odpowiedzialna za przygotowanie, a także prowadzenie szkoleń i ćwiczen ${ }^{19}$.

co konieczne (whatever is needed, wherever is needed), http://www.nationalguard.com/guard-basics/ what-is-the-national-guard-s-mission, 14 V 2012 r. [dostęp: 23 IX 2019].

15 Ibidem.

${ }^{16}$ U.S. Department of Homeland Security, National Response Plan, December 2004, https://fas. $\mathrm{org} / \mathrm{irp} / \mathrm{agency} / \mathrm{dhs} / \mathrm{nrp} . \mathrm{pdf}$, and U.S. Department of Homeland Security, Notice of Change to the National Response Plan, May 25, 2006, http://disability.law.uiowa.edu/dpn_hi/260.pdf [dostęp: 22 IX 2019].

17 U.S. Department of Homeland Security, National Incident Management System, March 1, 2004, s. 7, https://www.hsdl.org/?abstract\&did=482966 [dostęp: 22 IX 2019].

18 L.E. Davis, J. Rough, G. Cecchine, A. Gereben Schaefer, L.L. Zeman, Hurricane Katrina Lessons for Army Planning and Operations, Santa Monica 2007, s. 11-12, https://www.rand.org/ content/dam/rand/pubs/monographs/2007/RAND_MG 603.pdf [dostęp: 20 IX 2019].

19 J. FALECKI, op. cit., s. 113-115. 


\section{Operacja wojskowa w trakcie i po przejściu huraganu}

Siły zbrojne odegrały kluczową rolę w reakcji na huragan Katrina. Z taką potęgą żywiołu można próbować walczyć tylko przy dużym wsparciu ludzkim i technicznym. Skalę udziału wojska w operacji reagowania na skutki przejścia huraganu Katrina opisują następujące słowa: „Udział 72000 mężczyzn i kobiet w mundurach wojskowych w Stanach Zjednoczonych jest największą relokacją wojska w naszym kraju od czasów wojny secesyjnej. Zakres i szybkość [...] reagowania Departamentu Obrony na huragan Katrina była największą, najszybszą misją wsparcia obywateli w historii naszego kraju"20.

Prezydent George W. Bush wysłał na pomoc ofiarom kataklizmu okręty wojenne i 60 helikopterów. Wojsko pomagało w rozdzielaniu żywności i lekarstw, w ewakuacji, w akcjach ratowniczych. W Nowym Orleanie żołnierze otrzymali nawet rozkaz użycia broni wobec przestępców, którzy strzelali do helikopterów przywożących żywność i lekarstwa, przez co piloci nie mogli lądować ${ }^{21}$.

Udział wojska podczas takiego kataklizmu jest elementarnym działaniem $\mathrm{w}$ ramach zarządzania kryzysowego. Wojsko realizuje zadania w czterech fazach zarządzania kryzysowego: w zapobieganiu, przygotowaniu, reagowaniu i odbudowie. Podczas katastrof spowodowanych siłami natury, np. powodzi, prowadzi się ewakuację ludzi, inwentarza i dobytku, który jest zagrożony falą powodziową, likwiduje się wyrwy i szczeliny w wałach powodziowych, wypompowuje się wodę z obiektów, usuwa szkody i zagrożenia ekologiczne, wykonuje szczepienia ochronne, prowadzi dezynfekcję i dezynsekcję oraz deratyzację terenu. W przypadku pożarów ratuje się ludzi narażonych na działanie ognia i dymu, prowadzona jest akcja gaszenia i zapobiegania rozprzestrzenianiu się ognia. Podczas huraganów najczęściej udziela się pomocy medycznej poszkodowanym, odgruzowuje budynki, usuwa powalone drzewa, udrażnia się

${ }^{20}$ [The] movement of 72,000 men and women in military uniform within the United States is the largest deployment of military capability within our country since the Civil War. The scope and speed of [...] our DOD Katrina response, was the largest, fastest civil support mission in our nation's history. - Paul McHale, Assistant Secretary of Defense for Homeland Defense McHale interview, Jan. 4, 2006, p. 49, Aug. 29 and Sept. 10, 2005, [w:] Hurricane Katrina: A Nation Still Unprepared..., s. 474.

21 https://www.tygodnikprzeglad.pl/nowy-orlean-po-potopie/ [dostęp: 22 IX 2019]. 
zatarasowane szlaki komunikacyjne i likwiduje uszkodzenia linii energetycznych $^{22}$. Operacje wojskowe prowadzone w odpowiedzi na huragan Katrina były również wieloaspektowe. W fazie reagowania, która była prowadzona mimo ustąpienia huraganu, można wymienić trzy różne rodzaje operacji:

1) wstępne operacje poszukiwawczo-ratownicze w Luizjanie i Missisipi w tygodniu po burzy, prowadzone głównie przez śmigłowce,

2) ewakuacja centrum kongresowego i stadionu „Superdome” w Nowym Orleanie, również w tydzień po burzy, za pomocą naziemnych środków transportu,

3) operacje pomocy w Missisipi i Luizjanie, w tym dostawy lekarstw, wody, żywność, usuwanie śmieci, przywrócenie krytycznych sieci transportowych i komunikacyjnych oraz operacje poszukiwania i ratowania tzw. od domu do domu w Nowym Orleanie ${ }^{23}$.

Po uderzeniu huraganu zareagowały różne jednostki wojskowe, marynarki wojennej, piechoty morskiej i sił powietrznych. Dowództwo zaś transportowe USA działało w grupach zadaniowych - utworzono tzw. Joint Task Force Katrina.

Korpus inżynieryjny (Army Corps of Engineers), który według Krajowego Planu Reagowania ma wiodącą rolę w zakresie robót publicznych i inżynierii, zaczął zajmować się dostawą wody, lodu, zasilania awaryjnego i usuwania gruzu.

Zadania wojsk koncentrowały się na operacjach poszukiwawczych i ratowniczych, głównie wykorzystywano jednostki śmigłowców Sił Powietrznych i Gwardii Narodowej. W tym miejscu zaznaczyć należy, że jako pierwsze zareagowały śmigłowce Straży Przybrzeżnej i rozpoczęły operację w chwili uderzenia huraganu. W pierwszym tygodniu działań śmigłowce wykonały ponad 900 misji poszukiwawczo-ratowniczych, ewakuacyjnych i dostaw zaopatrzenia ${ }^{24}$.

Według raportu o udziale wojska w reagowaniu na huragan Katrina, decyzja o rozmieszczeniu armii i morskich sił lądowych została podjęta dopiero pięć dni po jego uderzeniu, mimo że zarówno armia, jak i żołnierze piechoty

${ }^{22}$ E. NowaK, Użycie jednostek wojskowych sit zbrojnych RP, [w:] Bezpieczeństwo i zarzadzanie kryzysowe - uwarunkowania XXI wieku. Wspótczesne aspekty zarządzania kryzysowego, red. A. MARJAŃSKi, M. WŁodARCZYK, Łódź 2011, Przedsiębiorczość i zarządzanie, t. 12, z. 2, s. 141-165.

${ }^{23}$ L.E. Davis, J. Rough, G. Cecchine, A. Gereben Schaefer, L.L. Zeman, op. cit., s. 38.

${ }^{24}$ Ibidem, s. 39. 
morskiej mają jednostki gotowe do reagowania na niepokoje społeczne i nieprzewidziane wydarzenia w kraju i za granicą. Wpływ na to mógł mieć fakt niewdrożenia podczas tych operacji ujednoliconego systemu kontroli i dowodzenia. Z kolei to spowodowało, że dostępne helikoptery w sposób niewystarczająco zorganizowany dołączały do akcji, aby ratować życie, co prowadziło do pominięcia części miejsc, gdzie ludzie oczekiwali na pomoc. Departament obrony Stanów Zjednoczonych wysyłał sprzęt komunikacyjny, udostępniał możliwości rozpoznania lotniczego, helikoptery, sprzęt transportowy i szpitale polowe. Początkowo cywilni i wojskowi decydenci ocenili, że pomoc Gwardii Narodowej będzie wystarczająca, w związku z czym nie użyto wojsk lądowych i morskich. Ostatecznie do Luizjany wysłano zarówno lekką piechotę, jak i pozostającą w stałej gotowości bojowej jedną z brygad 82 Dywizji Powietrznodesantowej, ogólnie uważaną za najszybciej rozlokowującą się siłę interwencyjną ${ }^{25}$.

Raport Kongresu z 2006 r. na temat huraganu Katrina ${ }^{26}$ prezentuje udział poszczególnych jednostek sił zbrojnych oraz zadania przez nie wykonywane pod rozkazami Północnego Dowództwa Stanów Zjednoczonych (NORTHCOM $)^{27}$. W walce z żywiłem uczestniczyły: jednostki Marynarki Wojennej, 82 Dywizja Powietrznodesantowa, Pierwsza Brygada Kawalerii Powietrznej 1 Dywizji Kawalerii w Fort Hood, Zespół Drugiej Brygady Bojowej 1 Dywizji Kawalerii, Korpus Piechoty Morskiej Stanów Zjednoczonych, 4 Dywizja Morska, Siły Powietrzne Stanów Zjednoczonych i Dowództwo Transportu USA (TRANSCOM) oraz najliczniejsza Gwardia Narodowa.

Do problemów z koordynacją w procesie reagowania w trakcie i po przejściu huraganu, w związku z czym reakcja wojska była spóźniona (głównie z powodu braku personelu cywilnego i wojskowych, środków transportu i środków

${ }^{25}$ Ibidem.

${ }^{26}$ Hurricane Katrina: A Nation Still Unprepare..., s. 467-550.

27 Północne dowództwo Stanów Zjednoczonych (US NORTHCOM) to jedno z jedenastu zjednoczonych dowództw bojowych armii USA. Zadaniem tego dowództwa jest zapewnienie wsparcia wojskowego władzom cywilnym w USA, a także ochrona terytorium i interesów narodowych Stanów Zjednoczonych na kontynencie (USA, Portoryko, Kanada, Meksyk, Bahamy) oraz w powietrzu, na lądzie i podejścia morskie do tych obszarów. To dowództwo wojskowe byłoby głównym obrońcą przed inwazją na kontynent amerykański. US NORTHCOM został utworzony 25 IV 2002 r., kiedy prezydent George W. Bush zatwierdził nowy zunifikowany plan dowodzenia po atakach z 11 IX. US NORTHCOM zaczął działać 1 X 2002 r., vide: U.S. Northern Command Office of History, A Short History of United States Northern Command, Dec. 31, 2012, https://www.northcom.mil/Portals/28/Documents/Supporting\%20documents/Historical/NORTHCOM\%20History.pdf [dostęp: 28 IX 2019]. 
pomocowych), przyczyniły się złożone struktury kontroli i dowodzenia oraz odległości dyslokacji jednostek względem miejsca kataklizmu.

Marynarka wojenna wysyłała ponad 20 okrętów i 100 samolotów do Zatoki Meksykańskiej, zapewniła szeroką gamę mobilnych platform do lądowania, obsługi samolotów, leczenia pacjentów, transportu ogromnych ilości towarów, a także zasobów lądowych, w tym batalionów inżynieryjnych Seabees i wsparcia logistycznego. W Stanach Zjednoczonych największym problemem w szybkości odpowiedzi na sytuacje kryzysowe są odległości między zdarzeniami a rejonem stacjonowania służb, które potrzebują czasu na dotarcie. Dlatego duży wkład w akcje poszukiwawczo-ratownicze miał pływający w Zatoce Meksykańskiej lotniskowiec USS Bataan. W pobliżu rozmieszczono także wiele innych statków i sił, w tym USS Swift, aby uzupełnić USS Bataan zapasami, oraz trzy statki wsparcia logistycznego i cztery amfibie poduszkowce do transportu materiałów do Nowego Orleanu. Wysłano także statek szpitalny USNS Comfort z wyspecjalizowanym personelem i sprzętem ${ }^{28}$. Marynarka wojenna rozmieściła w regionie katastrofy średnie i ciężkie śmigłowce z 15 eskadr w całym kraju. Łącznie użyto 50 samolotów rozmieszczonych w Jacksonville, Norfolk, Corpus Christi i San Diego, aby pomóc w poszukiwaniach i ratowaniu, ewakuacji i operacjach logistycznych. Śmigłowce H-53, o dużym udźwigu, uczestniczyły w naprawach wałów przeciwpowodziowych, zrzucając worki z piaskiem do wyłomów ${ }^{29}$.

Kolejnym rodzajem wojsk biorący udział w reagowaniu na skutki huraganu Katrina, szczególnie w Nowym Orleanie była 82 Dywizja Powietrznodesantowa z siedzibą w Fort Bragg, Karolina Północna, która składa się z około 3700 żołnierzy. Te, utrzymywane na wysokim poziomie gotowości, siły są przygotowane do rozmieszczenia w dowolnym miejscu na świecie w ciągu 18 godzin od otrzymania rozkazu. Dowództwo nakazało wojskom lądowym dostarczenie brygady do prowadzenia centrów dystrybucji i kontroli oraz zapewnienia bezpieczeństwa w pobliżu Nowego Orleanu. Zadaniem dywizji było przede wszystkim poszukiwanie i ratowanie, a następnie udzielanie pomocy humanitarnej oraz gotowość na wypadek kolejnych działań i konieczności stabilizacji sytuacji. Wojsko pomagało także w przywracaniu porządku na międzynarodowym lotnisku w Nowym Orleanie oraz w Convention Center, które nadal były centralnym punktem ewakuowanych w całym mieście. Współpracowało też

\footnotetext{
${ }^{28}$ Hurricane Katrina: A Nation Still Unprepared..., s. 488-490.

${ }^{29}$ Ibidem.
} 
z Gwardią Narodową w podziale miasta na sektory poszukiwań, wspomagało poszukiwania FEMA, dostarczając helikoptery, łodzie, ciężarówki i dodatkowych żołnierzy zespołom miejskich akcji poszukiwawczo-ratowniczych „Urban Search and Rescue" (USAR) ${ }^{30}$.

Pierwsza Brygada Kawalerii Powietrznej 1 Dywizji Kawalerii z Fort Hood w Teksasie, która składa się z jednostki lotniczej śmigłowców użytkowych UH-60 Black Hawk i śmigłowców ciężkich dalekiego zasięgu CH-47 Chinook oraz batalionu 1500 żołnierzy, na prośbę FEMA o wsparcie zespołów Rapid Needs Assessment (Zespoły Ocen Pilnych Potrzeb) w Luizjanie wysłała w rejon kataklizmu dwa śmigłowce UH-60. Następnie wysłała sześć dodatkowych śmigłowców do Nowego Orleanu, gdzie dołączyły do działań poszukiwawczo-ratowniczych Gwardii Narodowej w Luizjanie. Odgrywała rolę lotniczej grupy zadaniowej dowodzącej jednostkami lotnictwa wojskowego w koordynacji ze Strażą Przybrzeżną. Brygada przyłączyła się także do Joint Task Force Katrina. Do działań poszukiwawczo-ratowniczych, ewakuacji i dystrybucji żywności oraz wody włączono również medyczną jednostkę ewakuacyjną złożoną z dziewięciu śmigłowców. W sumie w trakcie i po przejściu huraganu wykorzystano 50 statków powietrznych ${ }^{31}$.

Zespół Drugiej Brygady Bojowej 1 Dywizji Kawalerii przygotował około 300 lekkich i ciężkich pojazdów do rozmieszczenia w celu poszukiwania i ratowania, ewakuacji, usuwania gruzu, kontroli handlu i dystrybucji towarów. Pierwsza Dywizja Kawalerii działała przede wszystkim w parafii Algier na południowym brzegu rzeki Missisipi, prowadząc, od drzwi do drzwi, akcje poszukiwawczo-ratownicze. Ewakuacja miała być dobrowolna. Żołnierze otrzymali wskazówki, jak pukać do drzwi, oferować żywność, wodę i pomoc. Wszyscy zostali poinformowani o zasadach użycia siły ${ }^{32}$. W celu zapewnienia możliwości egzekwowania prawa przez brygadę podczas patrolowania parafii dołączono do niej 133 Pułk Artylerii Polowej Gwardii Narodowej Teksasu.

30 Ibidem, s. 491-493.

${ }^{31}$ Hurricane Katrina: A Nation Still Unprepared..., s. 493.

32 Ustawa Posse Comitatus, zabrania federalnym siłom wojskowym angażowania się w obowiązki organów ścigania - obowiązuje reguła: „Siła będzie używana tylko w ostateczności. Jeśli musisz użyć siły, aby wypełnić swoje obowiązki, użyj minimalnej wymaganej siły”. („Force will be used only as last resort. If you must use force to fulfill your duties, use the minimum force required") vide: U.S. Department of Defense, Hurricane Katrina Comprehensive Review Task Force, Standing Rules for the Use of Force, Sept. 2, 2005, https://fas.org/sgp/crs/natsec/RL33095.pdf [dostęp: 25 IX 2019]. 
Korpus Piechoty Morskiej Stanów Zjednoczonych, II Grupa ekspedycyjna Piechoty Morskiej i 4 Dywizja Morska - podjęły dodatkowe działania przygotowawcze do rozmieszczenia dużych oddziałów, w tym elementu dowodzenia w Nowym Orleanie i wysyłania sprzętu inżynieryjnego za pośrednictwem okrętów Marynarki Wojennej. Rozmieściły także helikoptery i samoloty transportowe w bazie lotniczej marynarki wojennej Pensacola „Naval Air Station Pensacola” oraz sprzęt inżynierski na USS Iwo Jima. Wysłano również grupę uderzeniową i zwiadowczą, aby utworzyć kwaterę dowodzenia i kontroli na stacji lotnictwa morskiego Belle Chasse. W tym celu wykorzystano pięć samolotów przewożących 150 żołnierzy piechoty morskiej do Belle Chasse. Natomiast samoloty Hercules C-130s przetransportowały 1250 żołnierzy w rejon południowo-zachodniej Missisipi, do parafii St. Bernard i Dolnego Dziewiątego Oddziału w Nowym Orleanie, aby wykonywać misje poszukiwawcze i ratownicze oraz zadanie usunięcie gruzu w Slidell w Luizjanie ${ }^{33}$.

Siły Powietrzne Stanów Zjednoczonych i Dowództwo Transportu USA (TRANSCOM) były odpowiedzialne za wsparcie logistyczne i transportowe - naziemne, powietrzne i morskie operacji wojskowych, udzielały również pomocy Departamentowi Zdrowia i Opieki Społecznej w operacjach ewakuacji pacjentów. Dowództwo wykorzystało samoloty transportowe C-17 Globemaster III i C-5 Galaxy. Pierwszą otrzymaną misją, 28 sierpnia, było przetransportowanie ośmiu zespołów ratowniczych Swift Water z baz Travis i March Air Force Base w Kalifornii do Luizjany w celu poszukiwania i ratownictwa na powierzchni. Zorganizowano grupy reagowania awaryjnego, będące w pogotowiu do ponownego otwarcia portów lotniczych w Nowym Orleanie i Gulfport, które w trakcie huraganu zostały zalane, a ich systemy oświetleniowe i komunikacyjne uszkodzone. Grupy zadaniowe oceniały ich stan, przywracały oświetlenie, łączność i nawigację oraz przeprowadzały konserwację odlatujących samolotów. Operacje TRANSCOM na lotnisku obejmowały trzy rodzaje zadań: ewakuację pacjentów, ewakuację obywateli i transport ładunku. TRANSCOM dostarczył 15 samolotów transportowych - pięć C-17, C-5, a także C-130s - do ewakuacji pacjentów w ramach krajowego systemu ratunkowego ${ }^{34}$. TRANSCOM ewakuował drogą powietrzną 21000 osób z Nowego Orleanu, odegrał także ważną rolę

${ }^{33}$ Hurricane Katrina: A Nation Still Unprepared..., s. 494-495.

${ }^{34}$ National Disaster Medical System to system międzyagencyjny służący do ewakuacji pacjentów i osób o krytycznych potrzebach ze szpitali w razie nagłego wypadku, vide: Hurricane Katrina: A Nation Still Unprepared..., s. 491-496. 
w rozmieszczeniu 82 Dywizji Powietrznodesantowej oraz skierował dodatkowe samoloty umożliwiające przemieszczanie personelu, pojazdów, helikopterów i zapasów na międzynarodowe lotnisko w Nowym Orleanie ${ }^{35}$.

Główna rola w walce z huraganem Katrina i jego skutkami przypadła żołnierzom Gwardii Narodowej. Siły Gwardii Narodowej podlegają dowództwu gubernatora stanu lub terytorium, na którym mają siedzibę. Gubernatorzy mogą wezwać je do stanowego obowiązku świadczenia pomocy w razie katastrof. W przypadku walki z huraganem Katrina, gubernatorzy zwrócili się o pomoc oddziałów stanowych, wezwano także EMAC ${ }^{36}$, czyli siły gwardzistów z innych stanów i krajów. W sumie w stanach Missisipi i Luizjanie ze skutkami huraganu walczyło 50000 gwardzistów. Pochodzili oni z 45 stanów oraz Dystryktu Kolumbii, Wysp Dziewiczych i Portoryko. Cztery pozostałe stany wysłały również wojsko. Reakcja Gwardii Narodowej była bezprecedensowa zarówno pod względem jej ogólnego rozmiaru, jak i czasu przemieszczania się. Na szczeblu federalnym gwardia stanowi część ogólnych sił zbrojnych Stanów Zjednoczonych i podporządkowana jest prezydentowi USA, który pozostaje jej naczelnym dowódcą. Na szczeblu stanowym gwardziści podlegają gubernatorowi. Główne zadania jednostek stanowych związane są z niesieniem pomocy w trakcie klęsk żywiołowych, kontrolowaniem i likwidowaniem zamieszek wewnętrznych wśród ludności, wspieraniem władz cywilnych w wypadkach stanów zagrożenia, przy organizacji ewakuacji, systemów łączności, transportu i komunikacji ${ }^{37}$. Podstawowymi rodzajami formacji zbrojnych Gwardii Narodowej są Wojska Lądowe (Army National Guard) oraz Wojska Powietrzne (Air National Guard).

Podczas huraganu Katrina jednostki Gwardii Narodowej składały się głównie z Żandarmerii Wojskowej (Military Police) i sił zabezpieczenia, w tym jednostek transportu, lotnictwa i inżynierii. Podjęły one szereg zadań: udział w akcji ratowniczej, pomoc przy ewakuacji, pomoc, poszukiwania i ratownictwo,

35 Ibidem, s. 495-496.

${ }^{36}$ EMAC (Emergency Management Assistance Compact), czyli kompaktowa pomoc w nagłych wypadkach powstała na podstawie umowy o wzajemnej pomocy między państwami w zakresie udzielania pomocy cywilnej i wojskowej, vide: Granting the consent of Congress to the Emergency Management Assistance Compact, $104^{\text {th }}$ Congress Joint Resolution, „Public Law” 1996, s. 104-321, https://www.congress.gov/104/plaws/publ321/PLAW-104publ321.pdf [dostęp: 22 IX 2019].

37 A.M. Siarkowska, Wykorzystanie doświadczeń amerykańskiej Gwardii Narodowej w tworzeniu bezpieczeństwa Polski w XXI wieku, http://www.test.obronanarodowa.pl/artykuly/display/ wykorzystanie-doswiadczen-amerykanskiej-gwardii-narodowej-w-tworzeniu-bezpieczenstwa-polski -w-xxi-wieku [dostęp: 6 IX 2019]. 
bezpieczeństwo, transport i rozdzielanie towarów (lekarstwa, woda, żywność i lód), dystrybucja paliw, opieka medyczna, przywrócenie łączności, wsparcie organów ścigania, usuwanie gruzu oraz odbudowa uszkodzonej infrastruktury. Większość jednostek składała się z sił ogólnego przeznaczenia, ale były też jednostki inżynieryjne, lotnicze i medyczne ${ }^{38}$.

Podczas rozmieszczania w Missisipi i Luizjanie jednostki Gwardii Narodowej korzystały zarówno z transportu naziemnego, jak i powietrznego (komercyjnego i wojskowego), przy czym mniej więcej tyle samo personelu podróżowało drogą powietrzną, jak naziemną. Była to bezprecedensowa akcja z punktu widzenia rozmiaru i szybkiego czasu reagowania jednostek ${ }^{39}$.

Skala zniszczeń podczas huraganu Katrina spowodowała także konieczność wykorzystania wsparcia ze strony Paktu Północnoatlantyckiego (NATO). Euroatlantycki Ośrodek Koordynacji Reagowania w przypadku Katastrof (EADRCC) 29 sierpnia 2005 r. zaoferował pomoc Stanom Zjednoczonym, które wystąpiły z oficjalną o nią prośbą. Pomoc polegała na przetransportowaniu pilnie potrzebnych towarów z Europy do USA. Operacja z udziałem samolotów szkoleniowych i transportowych Powietrznego Systemu Wczesnego Ostrzegania (AEW) oraz środków transportu lotniczego i morskiego Sił Odpowiedzi NATO (NRF) polegała na wykonaniu 12 lotów towarowych. Przy użyciu samolotów B707 Trainer Cargo Aircraft, C-130 Hercules, Airbus A310 oraz An-124 Rusłan ${ }^{40}$, wynajętego od Ukrainy, dostarczono 189 ton towarów, w tym żywności, zestawów pierwszej pomocy, środków medycznych, generatorów i pomp wodnych ${ }^{41}$. W sumie wykonano około 90 godzin lotów z darami ${ }^{42}$. Pomoc udzielona przez Sojusz Północnoatlantycki była aktem solidarności i wsparcia w stosunku do szerokiej akcji reagowania prowadzonej przez Stany Zjednoczone. Należy tu także wziąć pod uwagę fakt, że to właśnie Stany Zjednoczone stanowią największą siłę NATO - jako członek organizacji w sposób oczywisty wymagały wsparcia pozostałych sojuszników.

\footnotetext{
${ }^{38}$ https://www.tygodnikprzeglad.pl/nowy-orlean-po-potopie/ [dostęp: 22 IX 2019].

39 L.E. Davis, J. Rough, G. Cecchine, A. Gereben Schaefer, L.L.Zeman, op.cit., s. 21-22.

40 Jednorazowo przetransportował 86 ton ładunku.

41 Support to the US in response to hurricane Katrina, Sep. 15, 2008 EADRCC - Operation https://www.nato.int/eadrcc/2005/katrina/index.htm [dostęp: 22 IX 2019].

${ }^{42}$ M. Jochems, Rosnaca rola NATO $w$ zakresie akcji humanitarnych, „Przegląd NATO” 2006, https://www.nato.int/docu/review/2006/issue1/polish/art4.html [dostęp: 22 IX 2019].
} 


\section{Podsumowanie}

Doświadczenia z huraganu Katrina spowodowały konieczność zmiany przepisów, zasad i procedur działania w sytuacji kryzysowej, które wprowadzono dopiero trzy lata po przejściu huraganu. Są to nowe standardy dla każdego zagrożenia, co oznacza bezzwłoczną organizację wcześniejszej ewakuacji. Realizację tego zapisu można zweryfikować śledząc doniesienia medialne o działaniach zapobiegawczych przed ponownym wystąpieniem np. huraganu, śnieżycy czy innych zagrożeń w Stanach Zjednoczonych. Kolejne usprawnienie, to przygotowanie i rozmieszczenie odpowiednich sił i środków reagowania kryzysowego tak, aby działania mogły zostać podjęte ad hoc i nie powtórzyła się sytuacja braku organizacji i planów działania z czasu przejścia Katriny (ludzie czekali na pomoc, która dopiero była organizowana). Za sprawne działania w zarządzaniu kryzysowym odpowiadają - Departament Bezpieczeństwa Krajowego Stanów Zjednoczonych i Federalna Agencja Zarządzania Kryzysowego (DHS, FEMA ${ }^{43}$ ). W ramach zmian zaktualizowano również ramowe plany reagowania kryzysowego. Prowadzone są regularne ćwiczenia w celu utrzymania sprawności reagowania i testowania procedur ${ }^{44}$. Warto podkreślić, że w prawie amerykańskim dokładnie określono stany i sytuacje, w których można użyć sił zbrojnych jako wsparcia władz cywilnych w wypadku klęsk żywiołowych, katastrof, do siłowego utrzymania, przestrzegania lub przywrócenia naruszonego prawa oraz działań antyterrorystycznych. Określono także zadania, jakie mogą realizować siły zbrojne w ramach tego wsparcia ${ }^{45}$, m.in. niesienie pomocy władzy i społeczeństwu w sytuacjach zagrożeń niemilitarnych (klęski żywiołowe, awarie i katastrofy techniczne), ale także w sytuacjach niewydolności

${ }^{43}$ Department of Homeland Security DHS, Federal Emergancy Management Agency FEMA. DHS został założony przez Kongres w 2002 r., w 2003 r. przejął główną kontrolę nad federalnymi działaniami związanymi z zarządzaniem katastrofami. FEMA, która stała się częścią DHS w 2003 r., jest główną agencją, której zadaniem jest koordynacja federalnej pomocy w przypadku katastrof. FEMA nie jest w większości operacyjnym dostawcą pomocy. Główną rolą FEMA jest raczej zarządzanie działaniami reszty rządu federalnego; https://www.fema.gov/about-agency [dostęp: 21 IX 2019].

${ }^{44}$ W. Peterson, Nowa wersja krajowej strategii skutecznego reagowania kryzysowego $w$ przypadku wystąpienia kataklizmu. Wnioski z przebiegu huraganu Katrina cz. II, „Bezpieczeństwo i Technika Pożarnicza" 2011, vol. 21, nr 1, s. 9-20.

45 J. FALECKI, op. cit., s. 109-128. 
organizacyjnej i wykonawczej stałych służb cywilnych w zagrożeniu ${ }^{46}$. Wśród przyczyn nieprawidłowego funkcjonowania systemów zarządzania kryzysowego podczas katastrof wymienia się niewłaściwą koordynację prac pomiędzy jednostkami operacyjnymi, błędy w procesie wymiany informacji pomiędzy jednostkami operacyjnymi i decyzyjnymi. Rolę jaką odegrały formacje militarne przed, w trakcie i po ustąpieniu huraganu Katrina należy przypisać poszczególnym podmiotom. Nie istnieje bowiem konieczność użycia sił zbrojnych Stanów Zjednoczonych przed wystąpieniem kataklizmu, czyli w fazie zapobiegania i przygotowania do jego nadejścia. Funkcje aktywnej jednostki pełni i pełniła w tym przypadku doskonale przygotowana Gwardia Narodowa, która w miarę negatywnego rozwoju sytuacji uzupełniała swoje siły w EMAC (siły gwardzistów z innych stanów i krajów). Gwardia Narodowa uczestniczyła w każdej z faz zarządzania kryzysowego podczas huraganu Katrina, w zapobieganiu, przygotowaniu, reagowaniu i odbudowie. Inaczej jednak wyglądała rola armii Stanów Zjednoczonych, która została użyta w trakcie sytuacji kryzysowej i po jej ustąpieniu, czyli w reagowaniu i odbudowie, mimo że dowództwo NORTHCOM na podstawie prognoz meteorologicznych i ostrzeżeń ogłosiło gotowość wojska 23/24 sierpnia 2005 r., w pierwszym dniu przejścia huraganu, czyli w fazie pomiędzy przygotowaniem a reagowaniem. Jednak bezpośrednia reakcja wojska nastąpiła dopiero w dniu 27/28 sierpnia, gdy huragan osiągnął V, najwyższą w skali Saffira-Simpsona, kategorię i zniszczył Nowy Orlean ${ }^{47}$.

Faktem jest, że największe jednostki, posiadające doskonałe wyposażenie, nie są w stanie przemieszczać się błyskawicznie, na relokację potrzebują kilkanaście godzin. Szybsze dotarcie w rejony, gdzie uderzył huragan z punktu widzenia fizycznego i bezpieczeństwa było niemożliwe. Należało odczekać, aż siła wiatru zmaleje do bezpiecznych prędkości. Bezsprzeczny pozostaje jednak fakt słusznej krytyki władz przedstawionej w raporcie Kongresu dotyczącym huraganu Katrina, gdzie dokładnie przeanalizowano kwestie dowodzenia i przygotowania do huraganu. Wiedziano, że uderzy on w wybrzeże Stanów Zjednoczonych, można więc było relokować wojsko wcześniej, ewakuować ludność, ale zgodnie z ówczesnymi procedurami do takiego działania konieczna jest decyzja

${ }^{46}$ K. GĄSIOREK, Udziat Sit Zbrojnych w ochronie ludności, [w:] Bezpieczeństwo i zarządzanie kryzysowe..., t. 12, z. 2, s. 121-140.

${ }^{47}$ Hurricane Katrina: A Nation Still Unprepared..., s. 478. 
prezydenta wydana na wyraźną prośbę gubernatorów stanów, którzy również nie wzięli pod uwagę wielkości zagrożenia i najwyższej w skali siły huraganu.

Rola humanitarnego wsparcia NATO, to także działanie w fazie reagowania i odbudowy. Niesienie pomocy ofiarom klęsk żywiołowych nie jest odpowiedzią na zapis artykułu 5. traktatu waszyngtońskiego. Uznane jest raczej za rodzaj operacji reagowania kryzysowego i dotyczy operacji humanitarnych ${ }^{48}$.

\section{BIBLIOGRAFIA}

\section{Opracowania}

Falecki J., Analiza systemów zarządzania kryzysowego wybranych państw w aspekcie bezpieczeństwa powszechnego, „Zeszyty Naukowe Wyższej Szkoły Humanitas. Zarządzanie” 2017 , t. 18 , nr 2, s. 109-128.

Gąsiorek K., Udziat Sit Zbrojnych w ochronie ludności, [w:] Bezpieczeństwo i zarzadzanie kryzysowe - uwarunkowania XXI wieku. Wspótczesne aspekty zarządzania kryzysowego, red. M. Włodarczyk, A. Marjański, Łódź 2011, Przedsiębiorczość i zarządzanie, t. 12, z. 2, s. 121-140.

Kiljan G., Krajowy system zarządzania kryzysowego w środowisku sieciocentrycznym, „Studia i Materiały Polskiego Stowarzyszenia Zarządzania Wiedzą” 2010, nr 33, s. 58-69.

Kompała D., Doświadczenia z wykorzystania lotnictwa woperacjach pomocy humanitarnej, „Zeszyty Naukowe Uniwersytetu Przyrodniczo-Humanistycznego. Administracja i Zarządzanie” 2013, nr 99, s. 273-291.

Nowak E., Użycie jednostek wojskowych sit zbrojnych RP, [w:] Bezpieczeństwo i zarzadzanie kryzysowe - uwarunkowania XXI wieku. Wspótczesne aspekty zarządzania kryzysowego, red. A. Marjański, M. Włodarczyk, Łódź 2011, Przedsiębiorczość i zarządzanie, t. 12, z. 2, s. 141-165.

Peterson W., Nowa wersja krajowej strategii skutecznego reagowania kryzysowego w przypadku wystapienia kataklizmu. Wnioski z przebiegu huraganu Katrina cz. II, „Bezpieczeństwo i Technika Pożarnicza" 2011, vol. 21, nr 1, s. 9-20.

48 D. Kompa£a, Doświadczenia z wykorzystania lotnictwa w operacjach pomocy humanitarnej, „Zeszyty Naukowe Uniwersytetu Przyrodniczo-Humanistycznego. Administracja i Zarządzanie” 2013, nr 99, s. 275. 


\section{Netografia}

Anderson A.C., The New Orleans Hurricane Protection System: What Went Wrong and Why, American Society of Civil Engineers, 2007, s. 12-13, https://biotech.law.lsu.edu/ katrina/reports/erpreport.pdf [dostęp: 22 IX 2019].

Davis L.E., Rough J., Cecchine G., Gereben Schaefer A., Zeman L.L., Hurricane Katrina Lessons for Army Planning and Operations, Santa Monica 2007, s. 11-12, https://www. rand.org/content/dam/rand/pubs/monographs/2007/RAND_MG 603.pdf [dostęp: 20 IX 2019].

Granting the consent of Congress to the Emergency Management Assistance Compact, $104^{\text {th }}$ Congress Joint Resolution, „Public Law”1996, s. 104-321, https://www.congress. gov/104/plaws/publ321/PLAW-104publ321.pdf [dostęp: 22 IX 2019].

Hurricane Katrina: A Nation Still Unprepared. Special Report Of The Committee On Homeland Security And Governmental Affairs United States Senate Together With Additional View, $109^{\text {th }}$ Congress $2^{\text {nd }}$ Session, Washington, 2006, https://www.congress.gov/109/ crpt/srpt322/CRPT-109srpt322.pdf [dostęp: 20 IX 2019].

Jochems M., Rosnąca rola NATO w zakresie akcji humanitarnych, „Przegląd NATO” 2006, https://www.nato.int/docu/review/2006/issue1/polish/art4.html [dostęp: 22 IX 2019].

Siarkowska A.M., Wykorzystanie doświadczeń amerykańskiej Gwardii Narodowej w tworzeniu bezpieczeństwa Polski w XXI wieku, http://www.test.obronanarodowa.pl/artykuly/ display/wykorzystanie-doswiadczen-amerykanskiej-gwardii-narodowej-w-tworzeniubezpieczenstwa-polski-w-xxi-wieku [dostęp: 6 IX 2019].

Support to the US in response to hurricane Katrina, Sep. 15, 2008 EADRCC - Operation https://www.nato.int/eadrcc/2005/katrina/index.htm [dostęp: 22 IX 2019].

U.S. Department of Defense, Hurricane Katrina Comprehensive Review Task Force, Standing Rules for the Use of Force, Sept. 2, 2005, https://fas.org/sgp/crs/natsec/RL33095. pdf [dostęp: 25 IX 2019].

U.S. Department of Homeland Security, National Incident Management System, March 1, 2004, s. 7, https://www.hsdl.org/?abstract\&did=482966 [dostęp: 22 IX 2019].

U.S. Department of Homeland Security, National Response Plan, December 2004, https://fas.org/irp/agency/dhs/nrp.pdf, and U.S. Department of Homeland Security, Notice of Change to the National Response Plan, May 25, 2006, http://disability.law. uiowa.edu/dpn_hi/260.pdf [dostęp: 22 IX 2019].

U.S. Northern Command Office of History, A Short History of United States Northern Command, Dec. 31, 2012, https://www.northcom.mil/Portals/28/Documents/Supporting\%20documents/Historical/NORTHCOM\%20History.pdf [dostęp: 28 IX 2019].

Wombwell J.A., Army Support During the Hurricane Katrina Disaster, „The Long War Series Occasional Paper” 29, Leavenworth 2009, s. 195, https://www.armyupress.army. mil/Portals/7/combat-studies-institute/csi-books/wombwell.pdf [dostęp: 24 IX 2019]. 
http://www.nationalguard.com/guard-basics/what-is-the-national-guard-s-mission, 14 maja 2012 r. [dostęp: 23 IX 2019].

https://tvnmeteo.tvn24.pl/informacje-pogoda/swiat27/10-lat-temu-przeszla-katrina-zginelo-1836-osob,177063,1,0.html [dostęp: 20 IX 2019].

https://wiadomosci.wp.pl/bilans-huraganu-katrina-6037193376342657a [dostęp: 20 IX 2019].

https://www.fema.gov/about-agency [dostęp: 21 IX 2019].

https://www.tygodnikprzeglad.pl/nowy-orlean-po-potopie/ [dostęp: 20 IX 2019].

\section{Katarzyna Derlatka}

\section{THE ROLE OF THE US NATIONAL GUARD THE ARMY AND NATO FORCES BEFORE, DURING AND AFTER HURRICANE KATRINA}

Summary. At the turn of August and September 2005, the American power turned out to be helpless against the strength of hurricane Katrina, which destroyed 234 thousand $\mathrm{km}^{2}$ in 19 states. Katrina was called the biggest catastrophe for the United States, it was a lesson in humility for the authorities that country should be prepared for any eventuality, anticipate as many scenarios as possible for each identified threat. One of the reasons for significant human and material losses was the lack of a developed and implemented national framework for emergency response, which would presume compulsory earlier evacuation of the population and faster involvement of services and the army. 72000 soldiers, including as many as $\mathbf{5 0 0 0 0}$ National Guard soldiers, participated in the rescue operation during and after hurricane Katrina. Ships, transport aircraft and helicopters were sent to help the victims of the disaster. The army helped in the distribution of food and medicine, in evacuation, in rescue operations, the transport of gifts and necessary livelihood. Military operations conducted in response to hurricane Katrina were multi-faceted. In the response phase search and rescue operations were carried out mainly by helicopters, evacuation of people by surface transport and assistance operations, including transport of supplies, garbage removal, restoration of critical transport and communication networks as well as search and rescue operations. The scale of damage during hurricane Katrina also necessitated the use of NATO support.

Keywords: Crisis Response, Hurricane Karina, Disasters, United States, US Army, National Guards, NATO 